\title{
LOMPAT JAUH
}

\author{
D \\ I \\ $\mathbf{S}$ \\ $\mathbf{U}$ \\ S \\ $\mathbf{U}$ \\ $\mathbf{N}$ \\ Oleh: \\ Reihan Amelia Putri \\ X MIA 3 \\ SMA Negeri 3 \\ Medan \\ 2020
}




\begin{abstract}
ABSTRAK
Penulisan makalah ini bertujuan untuk memberikan pengetahuan/ informasi seputar lompat jauh. Lompat merupakan salah satu cabang dari olahraga atletik. Lompat jauh adalah salat satu materi yang dipelajari di kelas X Sekolah Menengah Atas. Di makalah ini akan dibahas sedikit mengenai atletik di bagian awal. Setelah itu di makalah ini terdapat apa itu lompat jauh, bagaimana teknik melakukan lompat jauh, latihan yang dilakukan beserta prinsip-prinsip latihan, apa saja macam-macam gaya lompat beserta bagaimana cara melakukannya, penjelasan mengenai lapangan yang digunakan untuk lompat jauh, serta peraturan-peraturan yang terdapat pada permainan lompat jauh. Maka dari itu untuk mengetahuinya, dapat membaca makalah ini.

Kata kunci: lompat jauh
\end{abstract}

\title{
BAB I
}

\section{PENDAHULUAN}

\subsection{Identifikasi Masalah}

Dalam kehidupan modern manusia tidak dapat dipisahkan dari olahraga, baik sebagai arena adu prestasi maupun sebagai kebutuhan untuk menjaga kondisi tubuh agar tetap sehat. Olahraga mempunyai peranan yang penting dalam kehidupan manusia. Melalui olahraga dapat dibentuk manusia yang sehat jasmani, rohani serta mempunyai kepribadian, disiplin, sportifitas yang tinggi sehingga pada akhirnya akan terbentuk manusia yang berkualitas. Suatu kenyataan yang bisa diamati dalam dunia olahraga, menunjukkan kecenderungan adanya peningkatan prestasi olahraga yang pesat dari waktu kewaktu baik ditingkat daerah, nasional maupun internasional. Hal ini dapat dilihat dari pemecahan-pemecahan rekor yang terus dilakukan pada cabang olahraga tertentu, penampilan tehnik yang efektif dan efisien dengan ditunjang oleh kondisi fisik yang baik.

Dengan adanya kecendrungan prestasi yang meningkat, maka untuk berpartisipasi dan bersaing antar atlet dalam kegiatan olahraga prestasi harus dikembangkan kualitas fisik, tehnik, psikologi dan sosial yang dituntut oleh cabang olahraga tertentu. Oleh karena itu melalui pengembangan dan pembinaan di masyarakat, olahraga wajib diajarkan di sekolah- 
sekolah dari sekolah tingkat dasar, sekolah tingkat pertama sampai dengan sekolah tingkat menengah.

Dalam lompat jauh terdapat beberapa macam gaya atau sikap badan pada saat melayang di udara. Soegito dkk (1994 : 143) menyebutkan ada tiga cara sikap melayang yaitu: 1) gaya jongkok (waktu melayang bersikap jongkok), 2) gaya lenting (waktu di udara badan dilentingkan), dan 3) gaya jalan di udara (waktu melayang kaki bergerak seolah-olah berjalan di udara). Gaya lompat jauh yang paling sederhana untuk diajarkan pada pemula seperti siswa di SD adalah lompat jauh gaya jongkok. Tehnik lompat jauh gaya jongkok termasuk yang paling sederhana di banding dengan gaya yang lain.

Untuk mencapai prestasi yang baik di dalam lompat jauh perlu didukung dengan latihan yang baik melalui pendekatan-pendekatan ilmiah dengan melibatkan berbagai ilmu pengetahuan. Kaitannya dengan latihan untuk mencapai prestasi ada beberapa unsur yang perlu diperhatikan dan ditingkatkan. Unsur tersebut menurut M. Sajoto (1988 : 15) diantaranya adalah unsur fisik/kondisi fisik, unsur tehnik, unsur mental, unsur kematangan juara. Dari keempat unsur tersebut, ialah satu unsur yang merupakan faktor utama yaitu kondisi fisik, seperti pendapat dari Depdiknas (2000 : 101) bahwa salah satu unsur atau faktor penting untuk meraih suatu prestasi dalam olahraga adalah kondisi fisik, disamping penguasaan tehnik, taktik dan kemampuan mental.

\subsection{Rumusan Masalah}

1. Atletik

2. Lompat jauh

3. Teknik lompat jauh

4. Latihan lompat dan prinsip-prinsip latihan

5. Macam-macam gaya lompat jauh

6. Lapangan Lompat Jauh

7. Peraturan permainan lompat jauh 


\subsection{Tujuan Masalah}

1. Untuk mengetahui sekilas informasi mengenai atletik

2. Untuk mengetahui informasi mengenai lompat jauh

3. Untuk mengetahui teknik lompat jauh

4. Untuk mengetahui latihan lompat jauh dan prinsip-prinsip latihannya

5. Untuk mengetahui macam-macam gaya lompat jauh

6. Untuk mengetahui informasi tentang lapangan lompat jauh

7. Untuk mengetahui peraturan permainan lompat jauh

\section{BAB II \\ PEMBAHASAN}

\subsection{Atletik}

Dalam dunia olahraga, dikenal banyak sekali cabang olahraga, antara lain adalah atletik, permainan, senam dan beladiri. Dari keempat cabang olahraga tersebut, atletik mempunyai peranan penting, karena gerakan-gerakannya merupakan gerakan dasar bagi cabang olahraga lainnya. Atletik menurut Aip Syarifuddin (1992:2) berasal dari bahasa Yunani, yaitu Athlon yang artinya pertandingan, perlombaan, pergulatan atau perjuangan, sedangkan orang yang melakukannya dinamakan Athleta (Atlet). Dengan demikian dapatlah dikemukakan, bahwa atetik adalah salah satu cabang yang dipertandingkan atau diperlombakan yang meliputi atas nomor-nomor jalan, lari, lompat dan lempar.

Atletik merupakan dasar untuk melakukan bentuk-bentuk gerakan yang terdapat didalam cabang olahraga yang lainnya. Dengan mengikuti kegiatan latihan atletik, akan dapat diperoleh berbagai pengalaman yang sangat berguna dan bermanfaat bagi kehidupan, karena didalam melakukan kegiatan atletik akan dilatih kekuatan, kecepatan, kelentukan, kelincahan, ketepatan, daya tekan, koordinasi gerak, keuletan, kedisiplinan dan percaya diri serta bertanggung jawab (Aip Syarifuddin dan Muhadi, 1992/1993 : 60). 
Dalam cabang olahraga atletik ada empat nomor lompat yaitu nomor lompat jauh, lompat jangkit, lompat tinggi dan lompat tinggi galah. Lompat jauh merupakan salah satu nomor atletik yang wajib diajarkan di SD, SMP dan SMA.

\subsection{Lompat Jauh}

Lompat jauh merupakan salah satu nomor lompat dari cabang olahraga atletik. Lompat jauh menurut Aip Syarifuddin (1992 : 90) didefinisikan sebagai suatu bentuk gerakan melompat, mengangkat kaki keatas kedepan dalam upaya membawa titik berat badan selama mungkin diudara (melayang diudara) yang dilakukan dengan cepat dan dengan jalan melakukan tolakan pada satu kaki untuk mencapai jarak yang sejauh-jauhnya.

Lompat jauh merupakan suatu gerakan melompat menggunakan tumpuan satu kaki untuk mencapai jarak sejauh-jauhnya. Sasaran dan tujuan lompat jauh adalah untuk mencapai jarak lompatan sejauh mungkin kesebuah letak pendaratan atau bak lompat. Jarak lompatan diukur dari papan tolakan sampai batas terdekat dari letak pendaratan yang dihasilkan oleh bagian tubuh. Menurut Engkos Kosasih (1985:67) bahwa yang menjadi tujuan lompat jauh adalah mencapai jarak lompatan yang sejauh-jauhnya yang mempunyai empat unsur gerakan yaitu : awalan; tolakan; sikap badan di udara; sikap badan pada waktu jatuh atau mendarat. Dalam hal yang sama Yusuf Adisasmita (1992:65) berpendapat bahwa keempat unsur ini merupakan suatu kesatuan, yaitu urutan gerakan lompat yang tidak terputus.

Dalam lompat jauh terdapat beberapa macam gaya yang umum dipergunakan oleh para pelompat, yaitu : gaya jongkok, gaya menggantung atau disebut juga gaya lenting dan gaya jalan di udara. Perbedaan antara gaya lompatan yang satu dengan yang lainnya, ditandai oleh keadaan sikap badan si pelompat pada waktu melayang di udara (Aip Syarifuddin, 1992 : 93). Jadi mengenai awalan tumpuan / tolakan dan cara melakukan pendaratan dari ketiga gaya tersebut pada prinsipnya sama. Salah satu gaya yang digunakan dalam penelitian ini adalah gaya jongkok. Disebut gaya jongkok karena gerak dan sikap sewaktu badan berada diudara seperti orang jongkok ( Tamsir Riyadi, 1985: 98).

Untuk memperoleh hasil yang optimal dalam lompat jauh selain pelompat harus memiliki kondisi fisik yang baik, juga harus memahami dan mengusai tehnik untuk melakukan 
gerakan lompat jauh tersebut. Bernhard (1993 : 45) menyatakan bahwa unsur-unsur dalam mencapai prestasi lompat jauh yang maksimal adalah: 1) faktor kondisi fisik terutama kecepatan tenaga lompatan dan tujuan yang diarahkan pada ketrampilan, 2) faktor tehnik ancang-ancang, persiapan dan perpindahan fase melayang dan pendaratan.

Dari pendapat di atas dapat dikatakan bahwa dalam lompat jauh terkandung unsur-unsur kondisi fisik yang meliputi kecepatan, tenaga ledak otot tungkai yang mengarah pada ketrampilan.

\subsection{Teknik Lompat Jauh}

Lompat jauh mempunyai empat fase gerakan, yaitu awalan, tolakan, melayang dan mendarat serta terdapat tiga macam gaya yang membedakan antara gaya yang satu dengan gaya yang lainnya pada saat melayang diudara. Uraian mengenai keempat fase gerakan dalam lompat jauh adalah sebagai berikut.

\section{a. Awalan}

Awalan adalah langkah utama yang diperlukan oleh pelompat untuk memperoleh kecepatan pada waktu akan melompat. Seperti dikatakan Aip Syarifuddin (1992 : 90) awalan merupakan gerakan permulaan dalam bentuk lari untuk mendapatkan kecepatan pada waktu akan melakukan tolakan (lompatan). Jarak awalan yang biasa dan umum digunakan oleh para pelompat (atlet) dalam perlombaan lompat jauh adalah : 1) untuk putra antara $40 \mathrm{~m}$ sampai $50 \mathrm{~m}$; 2) untuk putri antara $30 \mathrm{~m}$ sampai dengan $45 \mathrm{~m}$. Akan tetapi di dalam pelaksanaan kegiatan belajar mengajar, terutama di SD hendaknya disesuaikan dengan kemampuan anak-anak SD. Misalnya antara $15 \mathrm{~m}$ sampai $20 \mathrm{~m}$ atau antara $15 \mathrm{~m}$ sampai $25 \mathrm{~m}$. Menurut Engkos kosasih (1985 : 67) awalan harus dilakukan dengan secepat-cepatnya serta jangan merubah langkah pada saat melompat. Menurut Aip Syarifuddin (1992 : 91) agar dapat menghasilkan daya tolakan yang besar, maka langkah dan awalan harus dilakukan dengan mantap dan menghentak-hentak (dinamis step). Untuk itu dalam melakukan lari awalan, bukan hanya kecepatan lari saja yang dibutuhkan, akan tetapi ketepatan langkah juga sangat dibutuhkan sebelum melakukan tolakan. 


\section{b. Tumpuan atau Tolakan}

Tumpuan atau tolakan adalah gerakan menolak sekuat-kuatnya dengan kaki yang terkuat, yaitu meneruskan kecepatan horizontal ke kekuatan vertical yang dilakukan secara cepat. Menurut Engkos Kosasih (1985 : 67) tolakan yaitu menolak sekuat-kuatnya pada papan tolakan dengan kaki terkuat ke atas (tinggi dan ke depan). Dengan demikian dapatlah dikatakan bahwa melakukan tolakan berarti jarak merubah kecepatan horizontal menjadi kecepatan vertical.

Mengenai tolakan, Soedarminto dan Soeparman (1993 : 360) mengemukakan sebagai berikut : untuk membantu tolakan ke atas, lengan harus diayun ke atas dan kaki yang melangkah diayunkan setinggi mungkin (prinsipnya adalah bahwa momentum dari bagian dipindahkan kepada keseluruhan). Ayunan kaki ke atas mengunci sendi panggul karena kerjanya Ligamenta iliofemoral.

Pada waktu menumpu seharusnya badan sudah condong kedepan, titik berat badan harus terletak agak dimuka titik sumber tenaga, yaitu kaki tumpu pada saat pelompat menumpu, letak titik berat badan ditentukan oleh panjang langkah terakhirsebelum melompat (Yusuf Adisasmita, 1992 : 67-68).

Dikatakan pula oleh Soegito dkk (1994 : 146) cara bertumpu pada balok tumpuan harus dengan kuat, tumit bertumpu lebih dahulu diteruskan dengan seluruh telapak kaki, pandangan mata tetap lurus kedepan agak ke atas.

c. Melayang di Udara

Sikap melayang adalah sikap setelah gerakan lompatan dilakukan dan badan sudah terangkat tinggi keatas. Menurut Aip Syarifuddin (1992 : 92/93) sikap dan gerakan badan di udara sangat erat hubungannya dengan kecepatan awalan dan kekuatan tolakan. Karena pada waktu pelompat lepas dari papan tolakan badan si pelompat akan dipengaruhi oleh suatu kekuatan yaitu gaya gravitasi (gaya penarik bumi).

Untuk itu, kecepatan lari awalan dan kekuatan pada waktu menolak harus dilakukan oleh pelompat untuk mengetahui daya tarik bumi tersebut. Dengan demikian jelas bahwa pada nomor lompat jauh kecepatan dan kekuatan sangat besar pengaruhnya terhadap hasil tolakan. Tetapi, dengan mengadakan suatu perbaikan bentuk dan cara-cara melompat serta mendarat, 
maka akan memperbaiki hasil lompatan. Perubahan dan perbaikan bentuk tersebut dinamakan “gaya lompatan” yang sifatnya individual. Pada nomor lompat (khususnya lompat jauh) perubahan bentuk akan gaya-gaya lompatan itu tidak akan mempengaruhi parabola dari titik berat badan, tetapi berguna untuk menjaga keseimbangan serta pandaratan yang lebih baik.

Menurut Engkos Kosasih (1985 : 67) sikap badan di udara adalah badan harus diusahakan melayang selama mungkin di udara serta dalam keadaan seimbang. Dalam hal yang sama Yusuf Adisasmita (1992 : 68) berpendapat bahwa pada waktu naik, badan harus dapat ditahan dalam keadaan sikap tubuh untuk menjaga keseimbangan dan untuk memungkinkan pendaratan lebih sempurna. Kalaupun mengadakan gerak yang lain harus dijaga agar gerak selama melayang itu tidak menimbulkan perlambatan. Pada lompat jauh, waktu melayang di udara berprinsip pada 3 hal sebagai berikut : 1) bergerak ke depan semakin cepat semakin baik: 2) menolak secara tepat dan kuat; 3) adapun gerakan yang dilakukan selama melayang di udara tidak akan menambah kecepatan gerak selama melayang dan hanya berperan untuk menjaga keseimbangan saja.

Cara melakukan lompat jauh gaya jongkok menurut Aip Syarifuddin (1992 : 93) pada waktu lepas dari tanah (papan tolakan) keadaan sikap badan di udara jongkok dengan jalan membulatkan badan dengan kedua lutut ditekuk, kedua tangan ke depan. Pada waktu akan mendarat kedua kaki dijulurkan ke depan kemudian mendarat pada kedua kaki dengan bagian tumit lebih dahulu, kedua tangan ke depan.

Pada prinsipnya sikap badan diudara bertujuan untuk berada selama mungkin diudara menjaga keseimbangan tubuh dan untuk mempersiapkan pendaratan. Sehubungan dengan itu diusahakan jangan sampai menimbulkan perlambatan dari kecepatan yang telah dicapai. Dengan demikian tubuh akan melayang lebih lama.

\section{d. Mendarat}

Mendarat adalah sikap jatuh dengan posisi kedua kaki menyentuh tanah secara bersama-sama dengan lutut dibengkokkan dan mengeper sehingga memungkinkan jatuhnya badan kearah depan. Seperti dikatakan Yusuf Adisasmita (1992 : 68) pada saat mendarat titik berat badan harus dibawa kemuka dengan jalan membungkukkan badan hingga lutut hampir merapat, dibantu pula dengan juluran tangan kemuka. Pada waktu mendarat ini lutut 
dibengkokkan sehingga memungkinkan suatu momentum membawa badan ke depan di atas kaki. Mendarat merupakan suatu gerakan terakhir dari rangkaian gerakan lompat jauh. Sikap mendarat pada lompat jauh baik untuk lompat jauh gaya jongkok, gaya menggantung maupun gaya jalan di udara adalah sama, yaitu : pada waktu akan mendarat kedua kaki dibawa ke depan lurus dengan cara mengangkat paha ke atas, badan dibungkukkan ke depan, kedua tangan ke depan, kemudian mendarat dengan kedua tumit terlebih dahulu dan mengeper, dengan kedua lutut ditekuk, berat badan dibawa kedepan supaya tidak jatuh dibelakang, kepala ditundukkan, kedua tangan ke depan (Aip Syarifuddin, 1992 : 95).

Gerakan mendarat dapat disimpulkan sebagai berikut : sebelum kaki menyentuh pasir dengan kedua tumit, kedua kaki dalam keadaan lurus ke depan, maka segara diikuti ayunan kedua lengan ke depan. Gerakan tersebut dimaksudkan supaya secepat mungkin terjadi perpindahan posisi titik berat badan yang semula berada di belakang kedua kaki berpindah ke depan, sehingga terjadi gerakan yang arahnya sesuai dengan arah lompatan dengan demikian tubuh akan terdorong ke depan setelah menginjak pasir. Untuk lebih jelasnya, gambar dibawah ini menunjukkan serangkaian gerakan lompat jauh gaya jongkok dari take-off sampai sikap mendara

\subsection{Latihan Lompat dan Prinsip-Prinsip Latihan}

a. Pengertian Latihan Lompat

Latihan adalah proses yang sistematis daripada berlatih atau bekerja secara berulangulang dengan kian hari kian menambah jumlah beban latihan atau pekerjaannya (Harsono, 1982 : 27). Lompat adalah istilah yang digunakan dalam cabang olahraga atletik, yaitu melakukan tolakan dengan satu kaki, Aip Syarifuddin (1992 : 90). Pengertian latihan lompat dari pendapat tersebut dapat disimpulkan yaitu melakukan gerakan melompat dengan tumpuan satu kaki yang dilakukan secara berulang-ulang dan setiap hari jumlah beban latihan ditambah. Latihan lompat yang dimaksud dalam penelitian ini adalah latihan lompat dengan melompati rintangan dan lompat meraih sasaran di atas.

Latihan lompat adalah metode yang terbaik untuk meningkatkan power maksimal pada otot tertentu. Cara yang paling baik untuk mengembangkan power maksimal pada 
kelompok otot tertentu, ialah dengan merenggangkan (memanjangkan) dahulu otot-otot tersebut secara eksplosif atau meledak-ledak. Untuk melatih power otot tungkai dimulai dengan gerakan tungkai kearah yang berlawanan (jongkok) yang disebut sebagai fase pre-regang (pre-stretching phase), kemudian melompat dengan kuat keatas. Setelah mendarat, tanpa adanya masa berhenti, kemudian secepatnya melompat lagi sekuat tenaga keatas, sehingga seakan-akan mendarat pada bara api (KONI, 2000: 27)

b. Prinsip-Prinsip Latihan

1) Prinsip Latihan Beban Bertambah ( Overload )

Untuk meningkatkan prestasi atlit prinsip overload harus digunakan. Apabila atlet sudah merasa ringan pada beban yang diberikan maka beban harus ditambah. Menurut M. Sajoto (1988 : 42) dengan berprinsip pada overload, maka kelompok-kelompok otot akan bergabung kekuatannya secara efektif dan akan merangsang penyesuaian fisiologis dalam tubuh yang mendorong meningkatkan kekuatan otot. Prinsip overload ini akan menjamin agar system di dalam tubuh yang menjalankan latihan, mendapat tekanan beban yang besarnya makin meningkat, serta diberikan secara bertahap dalam jangka waktu tertentu. Apabila tidak diberikan secara bertahap, maka komponen kekuatan tidak akan dapat mencapai tahap potensi sesuai fungsi kekuatan secara maksimal.

\section{2) Prinsip Peningkatan Beban Terus Menerus}

Otot yang menerima beban latihan lebih atau overload kekuatannya akan bertambah dan apabila kekuatan bertambah, maka program latihan berikutnya bila tidak ada penambahan beban, tidak lagi dapat menambah kekuatan. Penambahan beban dalam jumlah repetisi tertentu, otot belum merasakan lelah. Prinsip penambahan beban demikian dinamakan prinsip penambahan beban secara progresif. (M. Sajoto, 1988 : 115).

\section{3) Prinsip Urutan Pengaturan Suatu Latihan}

Latihan berbeban hendaknya diatur sedemikian rupa sehingga kelompok otot besar mendapat giliran latihan lebih dulu sebelum latihan otot kecil. Hal ini perlu agar kelompok otot kecil tidak mengalami kelelahan terlebih dahuu, sebelum kelompok otot mendapat giliran latihan 
pengaturan latihan hendaknya diprogramkan sedemikian rupa sehingga tidak terjadi dua bagian otot dalam tubuh yang sama mendapat dua giliran latihan secara berurutan (M. Sajoto, 1988 : 115)

\section{4) Prinsip Kekhususan Program Latihan}

Menurut O’shea dalam bukunya M. Sajoto (1988 : 42) menyatakan bahwa semua program latihan harus berdasarkan "SAID” yaitu Specific Adaptation to Imposed Demands. Prinsip tersebut menyatakan bahwa latihan hendaknya bersifat khusus, sesuai dengan sasaran yang akan dicapai. Bila akan meningkatkan kekuatan, maka program latihan harus memenuhi syarat untuk tujuan meningkatkan kekuatan.

Program latihan dengan beban dalam beberapa hal hendaknya bersifat khusus. Namun perlu memperhatikan pula gerak yang dihasilkan, oleh karena itu latihan berbeban hendaknya dikaitkan dengan latihan peningkatan ketrampilan motorik khusus. Dengan kata lain latihan beban menuju peningkatan kekuatan, hendaknya diprogram yang menuju nomor-nomor cabang

olahraga yang bersangkutan. Seperti diketahui bahwa untuk mendapatkan hasil lompatan yang jauh dalam lompat jauh perlu adanya bentuk latihan untuk meningkatkan daya ledak otot tungkai, latihan tersebut dapat dilakukan baik dengan menggunakan alat atau tanpa alat. Menggunakan alat dalam hal ini adalah latihan lompat dengan rintangan dan latihan lompat meraih sasaran di atas.

Selain keempat prinsip yang cukup mendasar untuk program latihan menurut Tohar (2004 : 54) program latihan dapat diatur dan dikontrol dengan cara memvariasikan beban latihan seperti volume, intensitas, recovery dan frekuensi dalam suatu unit program latihan harian. Volume menurut Depdikbud (1997 : 31) ialah kuantitas beban latihan yang biasa dinyatakan dengan satuan jarak, jumlah beberapa elemen jenis latihan, total waktu latihan, berat beban yang diangkat, jumlah set dalam latihan interval dan sirkuit sebagai ukuran rangsangan motorik dalam satu unit latihan. Intensitas menurut Tohar (2004 : 55) adalah takaran yang menunjukkan kadar atau tingkat pengeluaran energi, alat dalam aktivitas jasmani baik dalam latihan maupun pertandingan. Intensitas latihan plaiometrik dapat ditingkatkan dengan penambahan beban pada hal-hal tertentu dengan peningkatan ketinggian rintangan-rintangan 
(bilah) untuk depth jump atau dengan memperlebar jarak dalam longitudinal jump. Recovery dikatakan oleh Tohar (2004 : 55) adalah waktu yang digunakan untuk pemulihan tenaga kembali antara satu elemen materi latihan dengan elemen berikutnya. Menurut O'Shea yang dikutip oleh M. Sajoto (1988 : 48) mengatakan bila latihan lebih dari satu rangkaian, maka masa istirahat dalam rangkaian adalah antara 1-2 menit. Menurut Bompa yang dikutip oleh M. Sajoto mengatakan bahwa tes untuk mengevaluasi hasil latihan kekuatan dapat dilaksanakan setelah antara 4-6 minggu dari suatu masa siklus latihan makro. Frekuensi menurut Tohar (2004 : 55) adalah ulangan gerak beberapa kali atlet harus melakukan gerakan setiap giliran. Frekuensi tinggi berarti ulangan gerak banyak sekali dalam satu giliran. Frekuensi dapat juga diartikan berapa kali latihan per hari atau berapa hari latihan per minggu.

Dalam penelitian ini frekuensi latihan yang dipakai adalah tiga kali per minggu selama enam minggu. Sehingga tidak terjadi kelelahan yang kronis dengan lama latihan enam minggu tersebut.

\subsection{Macam-macam gaya lompat jauh}

\section{Lompat Jauh Gaya Jongkok (Gaya Orthodok)}

1) Antara 30 sampai 40 meter. Latihan kecepatan awalan dapat dilakukan dengan latihanlatihansprint 10 - 20 meter yang di lakukan berulang-ulang. Panjang langkah, jumlah langkah, dankecepatan berlari dalam mengambil awalan harus selalu sama. Menjelang tiga sampai empatlangkah sebelum balok tumpu, seorang pelompat harus dapat berkonsentrasi untuk dapatmelakukan tumpuan dengan kuat. Dengan catatan tanpa mengurangi kecepatan.

2) Tumpuan atau tolakan adalah perpindahan yang sangat cepat antara lari awalan danmelayang. Ketepatan tumpuan pada balok tumpu serta besarnya tenaga tolakan yangdihasilkan oleh kaki (explosive power) kaki sangatlah menentukan pencapaian hasillompatan. Oleh sebab itu, latihan ketepatan menumpu pada balok tumpu dapat dilakukandengan jumlah langkah sebanyak 5 hingga 7 langkah. Tumpuan kaki dapat di lakukan dengankaki kiri maupun kaki kanan tergantung dari kaki mana yang lebih kuat dan lebih dominan.Pada waktu menumpu badan condong ke depan, titik berat badan harus terletak agak kedepan, titik berat badan harus terletak agak ke depan. Titik sumber tenaga, yaitu kaki 
tumpumenumpu secara tepat pada balok tumpu, segera diikuti dengan gerakan kaki ayunkan kearah depan atas. Dengan sudut tolakan berkisar antara 40 - 50 derajat.

3) Melayang (sikap badan saat di udara) adalah setelah pelompat menumpu pada balok tumpuan, maka dengan posisi badan condong ke depan terangkat melayang di udara,bersamaan dengan ayunan kedua lengan ke depan atas. Untuk mendapatkan tinggi dan jauhnya lompatan harus meluruskan kaki tumpu selurus-lurusnya dan secepat-cepatnya. Padawaktu naik, badan harus dapat ditahan dalam keadaan rileks (tidak kaku) kemudianmelakukan gerakan-gerakan sikap tubuh di udara (waktu melayang) inilah biasanya yang disebut gaya lompatan dalam lompat jauh. Pada waktu di udara dengan sikap jongkok saat kakitolak menolakkan kaki pada balok tumpuan, kaki diayunkan ke depan atas untuk membantumengangkat titik berat badan ke atas kemudian diikuti kaki tolak menyusul kaki ayun. Saatmelayang ke dua kaki sedikit di tekuk sehingga posisi badan berada dalam sikap jongkok.Keadaan ini supaya dapat dipertahankan sebelum melakukan pendaratan.

4) Mendarat adalah pada waktu mendarat pelompat harus menjulurkan kedua belah tangansejauh-jauhnya ke muka dengan tidak kehilangan keseimbangan badannya supaya tidak jatuhke belakang. Untuk mencegahnya berat badan harus di bawa ke depan dengan caramembungkukkan badan dan lutut hampir merapat dibantu dengan cara menjulurkan tangankedepan. Pada waktu pendaratan lutut dibengkokan sehingga memungkinkan suatu momentum membawa badan ke depan atas kaki mendarat di lakukan dengan tumit terlebihdahulu mengenai tanah.

\section{Lompat Jauh Gaya Menggantung (Gaya Schnepper)}

Gaya menggantung merupakan salah satu gaya dalam lompat jauh. Mengapa di sebutgaya menggantung, karena gerak dan sikap badan di udara menyerupai dengan orang yangsedang menggantung atau melenting ke belakang. Yang harus dikuasai unsur-unsur dalammelakukan lompat jauh gaya menggantung adalah; awalan, tumpuan/tolakan, melayang danmendarat. Tanpa penguasaan teknik yang baik dan benar hasil yang diperolehnya tidak akanmaksimal. 
1) Awalan adalah gerak awal yang dimulai dengan lari, ini berguna untuk mendapatkankecepatan lari setinggi-tingginya sebelum mencapai balok tumpuan. Jarak awalan lari,tergantung pada tiap-tiap pelompat. Bagi para pemula mengambil awalan cukup 20 sampai25 meter, tetapi bagi atlet yang sudah mapan, untuk membangun kecepatan maksimum harusmengambil awalan antara 30 sampai 40 meter.

2) Tumpuan/tolakan merupakan perpindahan yang cepat antara lari, awalan dan melayang.Urutan melakukan tumpuan yang benar adalah:

-Tolakan dengan salah satu kaki yang lebih kuat dan dominan.

-Ketepatan tumpuan pada balok tumpu serta tenaga tolakan sangat menentukan hasillompatan.

-Pada saat kaki menumpu pada balok, badan harus agak condong ke depan.

-Titik berat badan harus terletek agak ke muka.

-Gerakan kaki ayun ke arah depan atas.

-Sudut tolakan kurang lebih 45 derajat.

3) Melayang (sikap badan saat di udara) adalah pelompat menumpu pada balok tumpuan, makabadan akan dapat terangkat di udara dengan sikap/gaya menggantung untuk melakukannya.

-Pada saat melayang kaki diayun dan diangkat ke depan.

-Kaki tolak selepas dari tanah diayunkan kembali ke belakang bersamaan atau sejajardengan kaki ayun.

-Sikap badan dibusungkan ke depan atau melenting ke belakang.

-Lengan diayunkan ke atas belakang.

-Kepala tengadah.

4) Mendarat adalah pada waktu mendarat pelompat harus berusaha menjulurkan kedua belahtangannya. Sejauh-jauhnya kemuka serta tidak kehilangan keseimbangan badannya. Pada saatini biasanya timbul perasaan, badan akan jatuh ke belakang, untuk 
mencegahnya titik beratharus di bawa ke depan dengan jalan membungkukan badan, hingga badan dan lutut hampirmerapat, dibantu pula dengan juluran tangan ke muka. Pada waktu pendaratan lututdibengkokan sehingga memungkinkan suatu momentum membawa ke depan atas, kakimendarat dilakukan dengan tumit terlebih dahulu mengenai tanah.

\section{Lompat Jauh Gaya Berjalan di Udara (Walking in the Air) Gaya berjalan di udara}

Merupakan salah satu gaya dalam lompat jauh. Mengapa di sebutgaya berjalan di udara, karena gerak dan sikap badan di udara menyerupai dengan orang yangsedang berjalan. Yang harus dikuasai unsur-unsur dalam melakukan lompat jauh gaya berjalan diudara adalah; awalan, tumpuan/tolakan, melayang dan mendarat. Tanpa penguasaan teknik yangbaik dan benar hasil yang diperolehnya tidak akan maksimal.

1) Awalan adalah saat melakukan awalan sebaiknya dilakukan pada jarak yang dirasakan cukupmemadai oleh pelompat. Pelompat memiliki naluri yang berbeda antara pelompat yang satudengan yang lainnya. Yang perlu dipahami oleh seorang pelompat jauh adalahpengembangan akselerasi, distribusi energi, dan kecepatan. Agar saat tolakan tepat, guru bisamenggunakan tanda pada lintasan yang akan dilalui pelompat.

2) Tumpuan adalah saat melakukan tumpuan dapat digunakan kaki kiri atau kanan sesuaidengan kebiasaan pelompat. Sebaiknya gunakan kaki yang memiliki kekuatan dominan.Ketika kaki menumpu ke balok badan harus dicondongkan ke depan agar keseimbangan tetapterjaga. Pandangan ke depan dengan kedua lengan berada di samping atas badan.

3) Melayang adalah setelah pelompat menumpu pada balok tumpuan, maka badan akan dapatterangkat ke udara. Dengan melakukan sikap berjalan di udara kedua kaki saling bergantian mengayuh di udara. Sebelum kaki mendarat upayakan berada dalam posisi di udara selama mungkin, agar menghasilkan lompatan maksimal.

4) Mendarat adalah pada waktu mendarat pelompat harus berusaha menjulurkan kedua belahtangannya ke depan dan kemudian ditarik ke belakang. Sementara kedua kaki dilujurkan ke depan sejauh mungkin. Daratkan kedua kaki secara bersamaan agar terhindar dari cedera.Jatuhkan berat badan ke depan. 


\subsection{Lapangan lompat jauh}

a) Catatan

- Bak lompat diisi dengan pasir

- Apabila pelompat gagal/diskualifikasi yuri mengangkat bendera merah

- Apabila pelompat melakukan dengan baik yuri mengangkat bendera putih

- Lebar awalan $122 \mathrm{~cm}$

- Panjang balok $122 \mathrm{~cm}$

- Lebar balok $20 \mathrm{~cm}$

b) Hal - hal yang perlu dihindari :

- Memperpendek atau memperpanjang langkah terakhir sebelum bertolak.

- Bertolak dari tumit dengan kecepatan yang tidak memadai.

- Badan miring jauh kedepan atau kebelakang.

- Fase yang tidak seimbang.

- Gerak kaki yang premature.

- Tak cukup angkatan kaki pada pendaratan.

- Satu kaki turun mendahului kaki lain pada darat.

c) Hal - hal yang harus diperhatikan/dilakukan

- pelihara kecepatan sampai saat menolak

- capailah dorongan yang cepat dan dinamis dan balok tumpuan.

- Rubahlah sedikit posisi lari, baertujuan mencapai posisi lebih tegak.

- Gunakan gerakan kompensasi lengan yang baik

- Capailah jangkuan gerak yang baik.

- Gerak akhir agar dibuwat lebih kuat dengan menggunakan lebih besar daya kepadanya. 
- Latihan gerakan pendaratan.

- Kuasai gerak yang betul dari lengan dan kaki dalam meluruakan dan membengkokkan.

-Ukuran:

a. Lebar lintasan awalan $=122 \mathrm{~cm}$

b. Lebar papan tumpu $=20 \mathrm{~cm}$

c. Panjang papan tumpu $=122 \mathrm{~cm}$

d. Bak lompat diisi dengan pasir

\subsection{Peraturan permainan lompat jauh}

1. Hal hal yang perlu diperhatikan untuk meraih hasil maksimal

-Jarak awalan 30-40 dan dilakukan secepat cepatnya

-Menggunakan kaki yang kuat untuk melakukan tolakan.

-Diusahakan melayang selama mungkin

-Waktu mendarat jangan sampai jatuh ke belakang

2. Diskualifikasi

-Dipanggil 3 menit belum melompat

-Menumpu dengan 2 kaki

-Kembali ke arah awalan, setelah melompat

-Mendarat luar bak lompat

-Juri mengangkat bendera merah apabila pelompat gagal

-Juri mengangkat bendera putih jika lompatan benar 


\section{BAB III}

\section{PENUTUP}

\section{A. Kesimpulan}

Berdasakan hasil pembahasan di atas, maka dapat menyimpulkan bahwa :

1. Ada perbedaan pengaruh antara latihan melompati rintangan dan meraih sasaran di atas terhadap kemampuan lompat jauh pada siswa SD, SMP dan SMA.

2. Latihan lompat dengan rintangan lebih baik pengaruhnya dari pada latihan lompat meraih sasaran di atas terhadap kemampuan lompat jauh pada siswa SD, SMP dan SMA.

\section{B. Saran}

Berdasarkan pada hasil akhir dari penelitian ini maka dapat diberikan saran bagi Guru Penjaskes dan pelatih untuk memperoleh hasil yang lebih baik dalam latihan daya ledak otot tungkai disarankan menggunakan bentuk latihan lompat dengan rintangan, karena sudah diuji bahwa latihan lompat dengan rintangan mempunyai pengaruh lebih baik dari pada latihan lompat meraih sasaran di atas terhadap kemampuan lompat jauh gaya jongkok. 


\section{DAFTAR PUSTAKA}

Aip Syarifuddin. 1992. Atletik. Jakarta : Depdikbud.

Aip Syarifuddin dan Muhadi. 1992/1993. Pendidikan Jasmani dan Kesehatan. Jakarta :

Depdikbud.

Bernhard, G. 1993. Atletik Prinsip Dasar Latihan Loncat Tinggi, Jauh, Jangkit dan Loncat

Galah. Terjemahan dari String Trainning voor. Djeugd. Semarang : Dahara Prize.

Carr, Gerry. 2000. Atletik (Edisi Terjemahan). Jakarta : PT. Raja Grafindo Persada.

Depdikbud. 2004. Kurikulum 2004 Standar Kompetensi SD dan MI. Jakarta: Dharma Bhakti.

------------. 1997. Kondisi Fisik Anak-anak Sekolah Dasar. Jakarta : Depdikbud.

Depdiknas. 2000. Pedoman dan Modal Pelatihan Kesehatan Olah Raga Bagi

PelatihOlahragawan Pelajar. Jakarta.

Engkos, Kosasih. 1985. Olahraga Tehnik dan Program Latihan. Jakarta. Akademika Pressindo.

Harsono. 1982. Ilmu Coaching. Jakarta: KONI Pusat.

J. Matakupan. 1996. TeoriBermain. Jakarta: Depdikbud

KONI. 2000. Panduan Kepelatihan. Jakarta: KONI.

M. Sajoto. 1988. Peningkatan dan Pembinaan Kekuatan Kondisi Fisik dalam Olahraga.

Semarang : Dahara Prize.

Nurhasan. 2001. Tes dan Pengukuran dalam Pendidikan Jasmani. Jakarta: Depdiknas. 